\title{
Does Accountability Undermine Service Delivery? The Impact of Devolving Agriculture in Ghana
}

\author{
Danielle Resnick ${ }^{1}[0$
}

Accepted: 11 May 2021 / Published online: 27 May 2021

(C) The Author(s) 2021

\begin{abstract}
In recent years, many developing countries have devolved services to locally elected governments. Although this may strengthen downwards accountability to citizens, does devolution improve service provision? Ghana began devolving agriculture in 2012 to its Metropolitan, Municipal, and District Assemblies (MMDAs). Drawing on an original survey with 80 District Directors of Agriculture and 960 households, as well as district-level budget data and interviews with national and local government stakeholders, this paper shows that agricultural expenditures and services have been negatively affected by the transition. The imperative of electoral accountability encourages assembly members to de-prioritize agriculture in the budget process in favor of more visible goods and services. Budget allocations, however, do reflect the preferences of local citizens, a majority of whom value using elections to sanction their district politicians. The findings indicate that devolution may increase accountability but result in sectoral trade-offs in service provision, which may undermine national policy objectives.
\end{abstract}

Keywords Accountability - Agriculture - Devolution · Ghana - Local government Service delivery

\section{Résumé}

Ces dernières années, de nombreux pays en développement ont délégué la prestation de services aux gouvernements locaux. Bien que cela puisse renforcer la redevabilité descendante envers les citoyens et citoyennes, la décentralisation améliore-t-elle la prestation de services? En 2012, le Ghana a commencé à déléguer le secteur de l'agriculture aux assemblées métropolitaines, municipales et de district. Cet article s'appuie sur une enquête originale auprès des directions de l'Agriculture dans 80 districts et auprès de 960 ménages, sur des données budgétaires émanant des districts ainsi que sur des entretiens avec les parties prenantes des gouvernements nationaux

Danielle Resnick

d.resnick@cgiar.org

1 Development Strategy and Governance Division, International Food Policy Research Institute (IFPRI), 1201 Eye Street NW, Washington, DC 20005, USA 
et locaux. Il montre ainsi que les dépenses et les services agricoles ont été impactés de façon négative par cette transition. Les impératifs qui vont de pair avec la redevabilité électorale encouragent les membres de l'assemblée à déprioriser l'agriculture dans le processus budgétaire, au profit de biens et de services plus visibles. Les allocations budgétaires, cependant, reflètent les préférences des citoyennes et citoyens locaux, dont une majorité trouve légitime de se servir des élections pour sanctionner les politiciens de leur district. Les résultats indiquent que la décentralisation peut accroître la redevabilité mais que cela entraîne des compromis en matière de prestation de services dans différents secteurs, ce qui peut entraver la réalisation des objectifs des politiques nationales.

\section{Introduction}

Accountability has long been viewed as essential for improved service provision (Joshi 2013; Mehrotra 2006). At its root, accountability requires government officials to explain their actions to the public and is accompanied by some form of enforcement to punish poor performance (Hickey and Mohan 2008; Schedler 1999). Elections are a key mechanism for strengthening downwards accountability between officials and citizens because the threat of being ousted through the ballot box theoretically creates incentives for politicians to ensure they provide goods and services (Cheibub and Przeworski 1999; Svolik 2013).

Devolution, which is the most comprehensive form of decentralization, potentially is a modality for reinforcing the linkages between accountability and service provision. By transferring responsibilities for service provision to elected local governments, politicians have a better idea of citizen priorities and can therefore deliver goods and services that best target their preferences (Wallace and Oates 1988). Local governments can therefore compete by pursuing 'preference matching, or tailoring the mix of goods and services they provide according to those preferences (Oates 1972; Tiebout 1956). In turn, the lines of authority for service provision are much more transparent to local citizens than when they remain under the mandate of the national government, thereby allowing voters to sanction or reward local politicians accordingly (Faguet 2014).

However, this study argues that devolution can increase accountability at the expense of reducing service provision. Specifically, if devolution enhances preferencing matching, and if politicians want to be responsive to those preferences, then the provision of certain goods and services-especially those that are visible to constituents - will be provided to a greater degree than those without those attributes. In particular, services for which attribution and credit is clearest, such as constructing roads, schools, and health clinics, would be expected to receive greater consideration by local politicians concerned with re-election than those with low visibility, such as teacher training or micronutrient fortification (Batley and McLoughlin 2015). Consequently, the improved accountability from devolution could result in a decrease in services that are essential for sustainable development.

Importantly, this argument differs from those who find that decentralization undermines development by replicating at the local level clientelist practices that 
prevail at the national level (e.g., D'Arcy and Cornell 2016; Maiorano et al. 2018). Under clientelism, politicians reward or punish citizens with certain goods and services according to whether they have, or plan, to vote for that individual (Stokes 2011). For example, inter-governmental transfers could be allocated according to whether a region or district disproportionately supported the ruling party in previous elections. Yet, this study is less concerned with the distribution of resources across geographic constituencies, or across supporters of different political candidates. Instead, it focuses more on how, by improving accountability and preference matching, decentralization affects the political economy of budgeting and service provision across sectors within local governments. Such dynamics can result in policy incoherence when national governments have simultaneously committed to specific sectoral spending goals.

Focusing on Ghana, this paper examines how improved accountability affects the budget for, and provision of, agricultural services. Since the 1993 Local Governance Act, Ghana thus far has practiced deconcentration whereby the national government oversees policy planning and local governments pursue implementation (Antwi-Boasiako 2010). To move closer to devolution, the government launched a number of reforms over the last decade, and in 2012, some sectors, including agriculture, were legally devolved to the country's Metropolitan, Municipal, and District Assemblies (MMDAs). At the same time, the Government has launched multiple strategies that emphasize the importance of agricultural services. For instance, the mission of the current Investing for Food and Jobs agenda is 'to promote sustainable agriculture and thriving agribusiness through research and technology development, effective extension and other support services to producers, processors, distributors and consumers for improved food security, nutrition and incomes' (MoFA 2018: 2).

To understand how the devolution of agricultural responsibilities has affected agricultural services, I surveyed 80 of the country's then 216 District Directors of Agriculture (DDAs) and 960 households. ${ }^{1}$ In addition, I analyzed district-level budget data available from 2012 to 2016 and conducted semi-structured interviews with the Ministry of Food and Agriculture (MoFA), the Ministry of Finance and Economic Planning (MoFEP), and district coordinating directors (DCDs) in selected MMDAs.

The findings show that citizens value the opportunity to keep their local politicians accountable. However, agricultural expenditures and services, particularly extension, have been negatively affected by the transition. The DDAs indicate that the imperative of electoral accountability encourages elected district assembly members to de-prioritize agriculture in the budget process. A key reason is that citizens are more likely to prefer visible investments in public works, schools, and health clinics rather than agriculture services.

The study offers three contributions. First, it contributes to the small but growing set of studies focused on bureaucrats in developing countries at the local level (see Brierley 2020; Gulzar and Pasquale 2017; Rasul and Rogger 2018). By surveying a sample of DDAs who experienced the transition from deconcentration to devolution,

\footnotetext{
1 At the time of fieldwork, Ghana had 216 districts. However, by 2018, there were 254 .
} 
the paper highlights how district-level budget changes impact bureaucrats' budgets and staffing. Second, despite the centrality of preference matching to decentralization theory, there is scant empirical analysis of citizens' actual policy preferences, a gap that this study begins to address. Third, the research has important policy implications since decentralization continues to proceed at varying speeds in most parts of the world, especially in unitary countries (OECD 2019). However, the findings show that devolving functions to subnational authorities can create trade-offs for meeting sectoral expenditure commitments and national development objectives.

\section{Devolution, Service Delivery, and Agriculture}

Decentralization encompasses a wide range of forms, with devolution constituting the most comprehensive version. Devolution involves granting local governments with the authority, responsibility, and resources to provide goods and services (Cheema and Rondinelli 2007). According to Smoke (2015), some form of subnational elections are a necessary condition for devolution to exist. Ideally, devolution enables democratically elected decision-makers to make decisions over development priorities in concert with citizens (Cheema and Rondinelli 2007).

Devolution theoretically can improve service provision through at least two main channels. First, by enabling local voters to sanction or reward politicians, it re-aligns their incentives to be accountable downwards to citizens rather than upwards toward national parties or ministries (Faguet 2014). Local elections also create more entrypoints into the political sphere, facilitating competition and pressuring local politicians to be more responsive to local needs (Faguet and Sanchez 2008).

Second, decentralization may provide improved information to both citizens and policymakers. Oates (1985) argued that citizens can be more demanding of the services they receive due to their better oversight abilities at the local level. In turn, they may feel more empowered to participate in decision-making and communicate their demands at that level than through national authorities, who may be too distant and anonymous (Brinkerhoff and Azfar 2010). Policymakers located closer to the citizens they serve can also more effectively learn about the preferences of those communities, which are believed to be more homogeneous than at the national level (Turner 2002; Wallace and Oates 1988). Local governments can therefore engage in inter-jurisdictional competition by pursuing preference matching, or tailoring the mix of goods and services they provide according to those preferences (Oates 1972; Tiebout 1956).

There is some empirical support for these different channels (e.g., Arze del Granado et al. 2018; Faguet 2012). Yet, if devolution increases politicians' accountability to local citizens, and if politicians' election prospects are tied to matching the preferences of local citizens, then devolution conceivably can lead to a bias toward more visible goods and services. 'Visibility' depends on a number of characteristics. For instance, public goods with short-term outcomes, such as the creation of a primary health clinic, are seen to be more 'visible' than those whose benefits manifest over the longer term, such as improved medical training for nurses (Rogoff 1990). In addition, the intrinsic visibility of a public good depends on how easily the quality 
of the outcome can be discerned and whether it depends on a complex interaction of factors that hinders attribution to any one overriding variable (Batley and Mcloughin 2015).

There is already a well-established literature that shows how African citizens value the receipt of material benefits from their parliamentarians above their executive oversight and legislation drafting roles (Barkan and Okumu 1974; Lindberg 2010). Furthermore, many studies on electoral accountability suggest that voters sanction or reward their politicians, depending on the quality of visible public goods (Golden and Min 2013; Mani and Mukand 2007), or their expectations of what the quality should be (de Kadt and Lieberman 2017). For instance, Harding (2015) shows that Ghanaian voters hold politicians accountable for visible road investments but not for the quality of education, which is lower visibility and harder to assess. Precisely because of their closer proximity to constituents, local politicians are even more likely than national ones to be compelled to respond to such preferences (Akin et al. 2005; Besley and Ghatak 2007; Hasnain 2010).

Variations in political institutions can make such dynamics more pronounced. Specifically, if local elections are not concurrent with presidential or parliamentary ones, then they are more likely to focus on local issues rather than national ones (Eaton et al. 2010). In this scenario, the prospect of politicians responding to the preferences of local citizens is higher. Additionally, Skoufas et al. (2014) argue that if local politicians can be elected as individuals and are not attached to a strong national party, then they may be more interested in local performance and responsiveness.

What are the implications of this existing scholarship for agriculture? On the one hand, due to variations in agroecological conditions, agricultural services need to be properly differentiated at the subnational level and therefore, agricultural producers would benefit from greater coherence between their local preferences and local government expenditures for the sector. On the other hand, agricultural services are directly relevant to only a select group of residents, e.g., farmers, compared to other sectors, such as infrastructure, health, and education, which are relevant to everyone. As such, one would expect that the imperative of accountability leads local politicians to favor other sectors over agriculture in terms of expenditure priorities.

This is especially true when authority for less visible public goods, such as agricultural extension, has been devolved to local politicians. Agricultural extension involves, inter-alia, educating farmers about seed varieties, pesticide use, conservation practices, and market opportunities. Publicly provided agricultural extension is a quintessential, low visibility public good for two reasons. First, it involves a transfer of a non-tangible item, i.e., knowledge, and it is difficult to discern the value of that knowledge in the short-term since the benefits of extension advice only manifest in the long term, or at least within an agricultural season. Moreover, attribution is difficult since extension agent advice can be undermined by bad weather, economic shocks, and improper implementation (Anderson 2007). Second, when provided freely by the government, such knowledge is both non-excludable and nonrivalrous, i.e., it cannot just be limited to certain groups of farmers and when one person takes advantage of extension advice, it does not reduce the supply available to others (Umali-Deininger 1997). Empirical analysis consistently highlights that the 
returns to public investment in extension, and associated impacts on poverty reduction and food security, are higher than expenditures on more visible infrastructure, such as roads and irrigation, or input subsidies (Pauw and Thurlow 2015; Ragasa and Mazunda 2018). However, low visibility is a key reason why governments typically underinvest in it (Mogues 2015).

In sum, citizens have hierarchies of preferences and will typically prioritize more visible and more targeted goods and services over less visible and more diffuse options. If decentralization is indeed a way of preference matching, then it is expected that politicians will favor the outlay of resources to match these preferences. A consequence is that while downwards accountability between politicians and citizens is improved, budgeted expenditures for less visible, more diffuse goods and services will be minimized.

\section{Devolution and Local Government in Ghana}

The argument elaborated above is applied to the case of Ghana, which commenced its decentralization process with the 1992 Constitution and the 1993 Local Government Act. Many scholars, however, lamented that the process remained limited and approximated deconcentration rather than devolution (e.g., Antwi-Boasiako 2010; Yeboah-Assiamah 2016). The sectoral units within the MMDAs were accountable upwards to their respective line ministries. However, in 2009, the Parliament passed Local Government Instrument 1961, which devolved responsibility for some sectors and functions from the line ministries to the MMDAs. A composite budget system was introduced, which integrates the budgets of all the separate departments of the MMDAs into the overall budgets of the MMDAs, and the finances for devolved functions are transferred directly from MoFEP to the MMDAs and no longer from the line ministries (Mogues and Omusu-Baah 2014). In 2012, the devolution process formally began when agriculture, along with public works and social welfare-known as schedule 1 areas-formally were devolved. This meant that the Department of Agriculture at the local level officially became part of the MMDA administration rather than reporting to its previous line ministry, MoFA. This was complemented by the transfer of over 33,000 staff from the central government civil service to the MMDAs; these staff were now hired and fired by the Local Government Services Secretariat based on needs and reports of the MMDAs (Mogues and Omusu-Baah 2014).

These agricultural departments were then allocated 25 functions, ranging from the provision of extension services, promoting soil and water conservation measures, and developing early warning systems on animal diseases (GoG 2009). Most of these functions are low visibility to citizens because their impact will only manifest over the longer term. Importantly, the devolution process was sectorally sequenced and for legal reasons, the education and health sectors had not been devolved during the time period of this study. Similar to Opalo's (2020) study on Kenya's devolution process, where policy autonomy has proceeded unevenly, this variation in sequencing allows for comparisons across time within the same sectors as well as between devolved and deconcentrated sectors. 
These reforms need to be understood vis-à-vis the existing institutional structure of the MMDAs. Within the political branch of the MMDAs, $70 \%$ of the members are elected by citizens every four years in elections that are non-concurrent with presidential and parliamentary ones. While the political leaning of elected members may be known (Williams 2017), Ghana legally bars local assembly members from competing on a partisan basis. The remaining $30 \%$ of MMDA members are nominated by the president. This includes the District Chief Executive (DCE), who is equivalent to a mayor. On the bureaucratic side, the head civil servant is the District Coordinating Director (DCD).

Under the composite budgeting system, the MMDA works with each department to plan a budget annually based on funds from the central government, donors, and internally generated revenue. Subsequently, the Executive Committee (ExCo) of the MMDA will accept or reject the budget. The ExCo includes one-third of the assembly members and is overseen by the DCE and a Presiding Member of the assembly elected by his/her peers (Williams 2017). Upon approval, the budget goes to the General Assembly for approval, rejection, or amendment by all assembly members in the MMDA. ${ }^{2}$ It is then submitted to the Regional Coordinating Councils, which coordinate the budgets for the respective region before submitting to MoFEP (GoG 2016). In sum, the budgeting process will emanate from the departmental bureaucrats, but its ultimate approval relies heavily on local politicians.

\section{Trends in Sectoral Spending}

As Arze del Granado et al. (2018, p. 360) elaborate, 'implicit in the argument that decentralization can increase allocative efficiency, is the implication that decentralization is likely to alter the composition of public expenditures.' As such, I first examine shifts in sectoral public spending at the MMDA level as a result of devolution by utilizing the composite budgets for all districts provided by MoFEP. ${ }^{3}$

Table 1 presents the sectoral shares of budgeted expenditures by year for those districts for which full sectoral data was available. ${ }^{4}$ The budgets for the fiscal year 2012 were conducted in the 2011 calendar year, prior to the legal implementation of devolution for schedule 1 areas and therefore provide a baseline for assessing subsequent expenditure decisions. The data focuses on budgeted expenditures because they are more reflective of the intentions of the MMDA and more directly impacted by the collective decisions of the assembly members.

Central administration declined in the budget since 2012; the saved resources went into health and public works over time while agriculture's share of total district expenditures plateaued.

\footnotetext{
2 Interview with MoFEP's Fiscal Decentralization Unit (Accra), October 2016 and DCDs in Central and Eastern regions, May 2017.

3 This data is available at http://www.mofep.gov.gh/publications/composite-budget.

4 Although more recent composite budget data is available, there are more missing entries, which compromises the sample size.
} 
Table 1 Average MMDA budgeted expenditures by sector as share of total expenditures (\%), across districts

\begin{tabular}{llllll}
\hline Sector & 2012 & 2013 & 2014 & 2015 & 2016 \\
\hline Agriculture $^{\mathrm{a}}$ & 7.5 & 8.6 & 7.7 & 6.9 & 7.4 \\
Central Administration & 52.3 & 48.3 & 47.5 & 43.0 & 41.2 \\
Disaster Prevention & 0.7 & 0.5 & 0.8 & 0.9 & 0.7 \\
Education, Sports, \& Youth & 17.8 & 19.0 & 17.5 & 18.9 & 17.3 \\
Health & 8.1 & 8.9 & 9.5 & 10.9 & 13.7 \\
Physical Planning & 1.0 & 0.9 & 1.5 & 1.4 & 1.6 \\
Social Welfare \& Commu- $^{\text {nity Development }}{ }^{\mathrm{a}}$ & 1.1 & 2.0 & 2.6 & 3.1 & 3.2 \\
$\quad$ Works & & & & & \\
Number of districts & 10.9 & 11.7 & 12.9 & 14.9 & 14.9 \\
\hline
\end{tabular}

Source Calculated from district composite budgets from MoFEP. Notes The shares are based on sectoral totals that aggregate to the district-level departments and exclude sectors that are only relevant to the municipal and metropolitan assemblies.

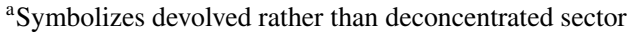

Figures 1 and 2 show the distribution of total budgeted agriculture and public works expenditures, in real terms, over time for the sample of MMDAs for which such data is available for both sectors for every year. These two sectors offer the most rigorous possible comparison since, as noted above, they were among the earliest sectors to be devolved. By contrast, sectors such as health and education are still deconcentrated departments, receiving money from both the MMDAs and their line ministries. The comparison of these figures highlights that the median total of Ghanaian cedi (GHS) allocated to agriculture by MMDA declined from 328,890 to 209,007 between 2012 and 2016, equivalent to a $36 \%$ reduction. ${ }^{5}$ During the same period, however, the median spending on public works increased by $24 \%$. Since agricultural expenditures would be most relevant for those households with at least one family member employed in the sector, Fig. 3 also examines the average share of budget expenditures per agricultural household across the same districts. Again, it shows declines in spending within the sector since 2012.

If expenditure decisions were purely determined based on needs, one would expect that devolution would have enabled those local governments with a higher share of their populations employed in agriculture to shift their money to that sector. However, Fig. 4 illustrates that the average shift in budgeted expenditures between 2012-2013 and 2015-2016 did not reflect this pattern; districts with a large share of their labor force in agricultural employment were no more likely to receive more spending on agriculture than those with a smaller share. This suggests that expenditure decisions are influenced by more than just socioeconomic needs.

One alternative explanation for expenditure patterns could be attributed to the creation of 46 new districts in 2012. New districts might be expected to implement

\footnotetext{
5 At the time of fieldwork in 2017, 1 USD $=$ GHS 4.2.
}

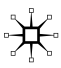




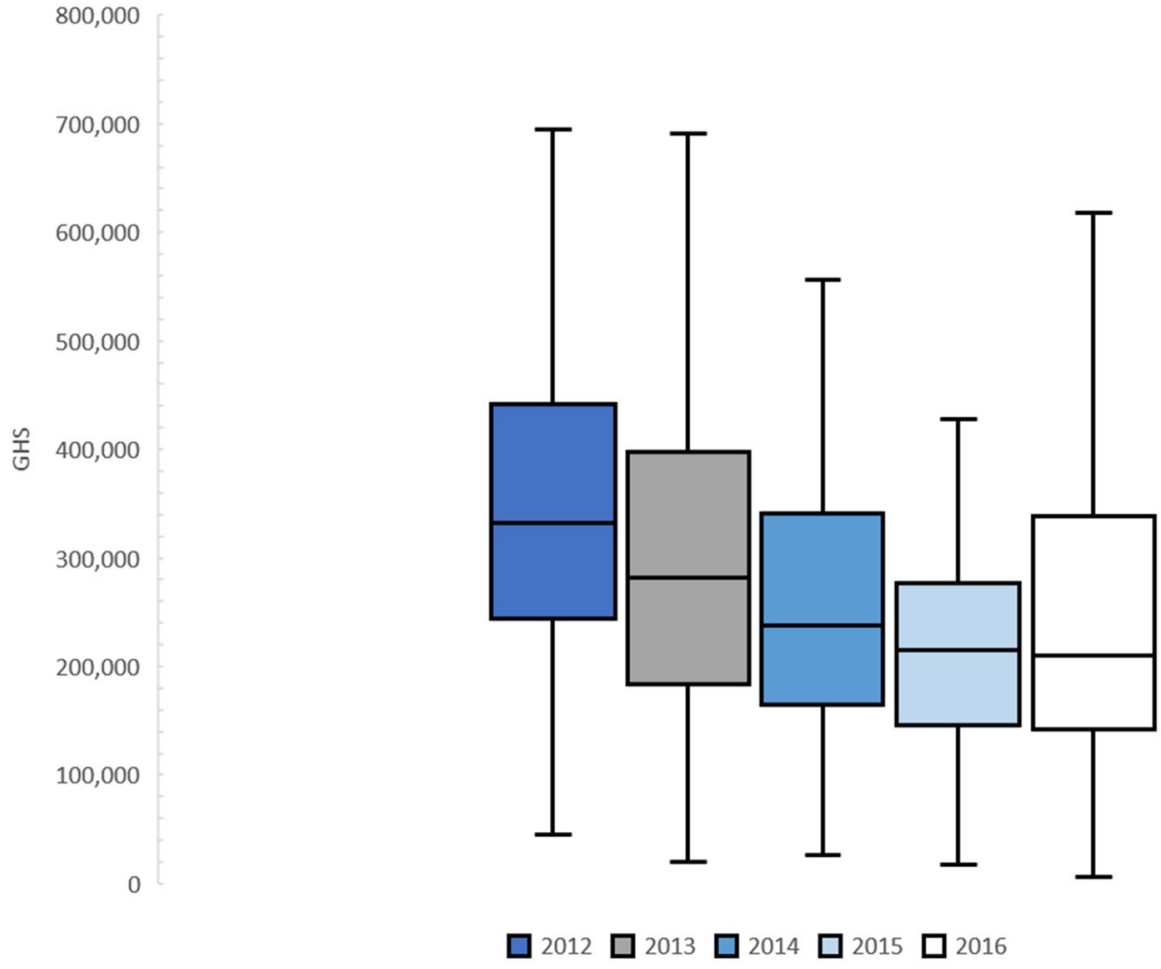

Fig. 1 Distribution of total budgeted expenditures for agriculture across MMDAs, real terms. Source Calculation from district composite budgets for 123 districts. The budgets were all converted to real terms using the GDP deflator from the World Development Indicators, with 2012 as the base year. Notes The line in the middle of the box signifies the median. The top of the boxes capture the third quartile and the bottom of the boxes refer to the first quartile. The bars extending downwards and upwards refer to the minimum and maximum values, respectively. (Color figure online)

new infrastructure projects because they need to build new MMDA office buildings and marketplaces. If so, one might expect that agricultural expenditures were especially disadvantaged in newly created districts and diverted to public works. However, the black dots in Fig. 4, which symbolize the new districts, suggest that this was not the case.

\section{Perceived Impacts of Devolution by Bureaucrats and Citizens}

To supplement this expenditure data, a survey was implemented with 80 District Directors of Agriculture (DDA). ${ }^{6}$ The DDA survey sample was based on a clustered, stratified, probability sample. Specifically, the sample of MMDAs was stratified

\footnotetext{
${ }^{6}$ Interviews occurred in October 2016 and May 2017. The household and DDA surveys occurred between March 23-April 11, 2017 and May 3-24, 2017, respectively.
} 


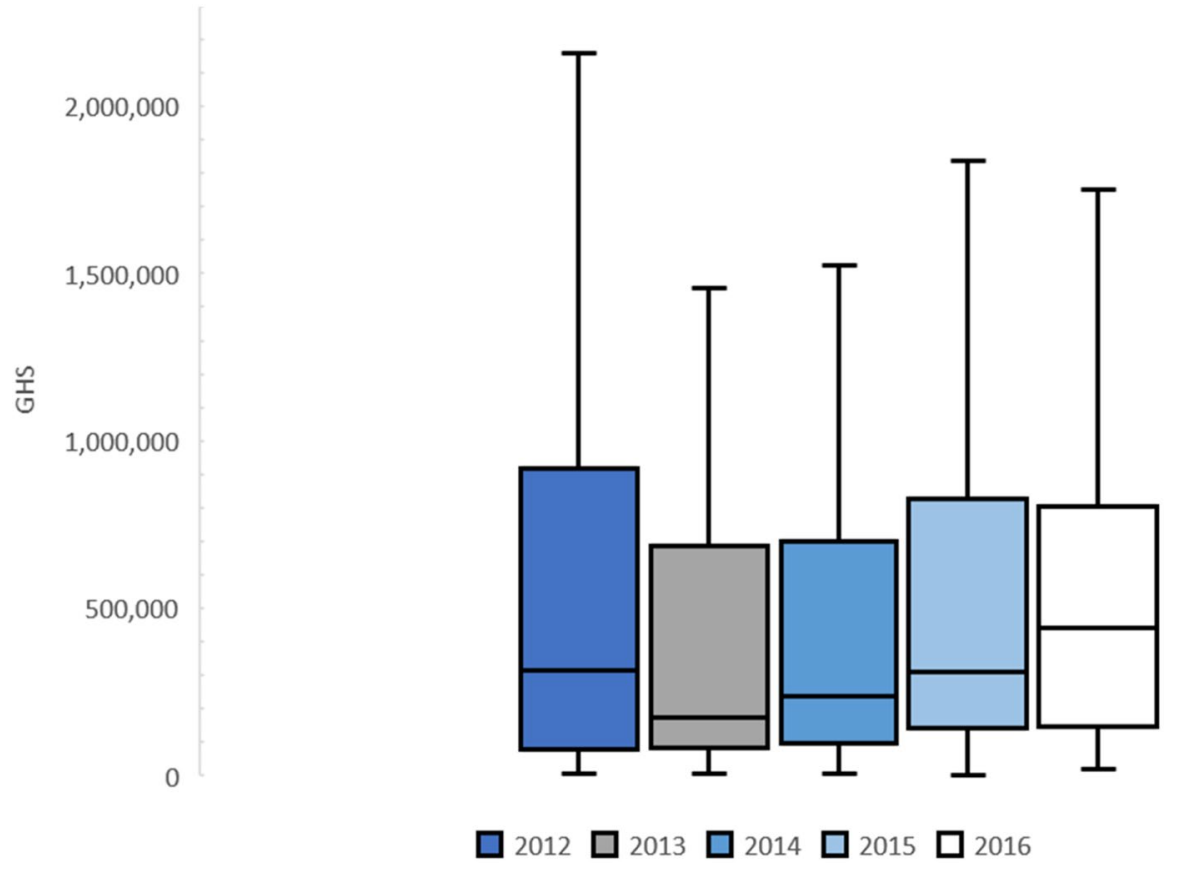

Fig. 2 Distribution of total budgeted expenditures for public works across MMDAs, real terms. Source Calculation from district composite budgets for 123 districts. The budgets were all converted to real terms using the GDP deflator from the World Development Indicators, with 2012 the base year. Notes The line in the middle of the box signifies the median. The top of the boxes capture the third quartile and the bottom of the boxes refer to the first quartile. The bars extending downwards and upwards refer to the minimum and maximum values, respectively. (Color figure online)

according to the country's then 10 regions and proportional to the rural and urban populations for each region based on the 2010 National Housing and Population Census. ${ }^{7}$ In turn, eight MMDAs per region were randomly selected, providing a total of 80 MMDAs. Selected districts are shaded in Fig. 5 below, and they vary significantly with respect to population levels, poverty, and share of employment in agriculture (see Table 2).

A survey was also conducted with predominantly rural households in six of the ten regions: Ashanti, Brong-Ahafo, Northern, Upper East, Volta, and Western. The same MMDAs that were selected for those six regions in the DDA sample were retained for the household surveys, resulting in 48 districts that overlap for the two surveys. These are identified with the hatched shading in Fig. 5.

For each MMDA in the sample, two enumeration areas were randomly selected from the main list of communities available from district census reports (GSS 2014). A total of 10 households were selected within each enumeration area using a

\footnotetext{
7 By 2018, Ghana had 16 regions.
} 


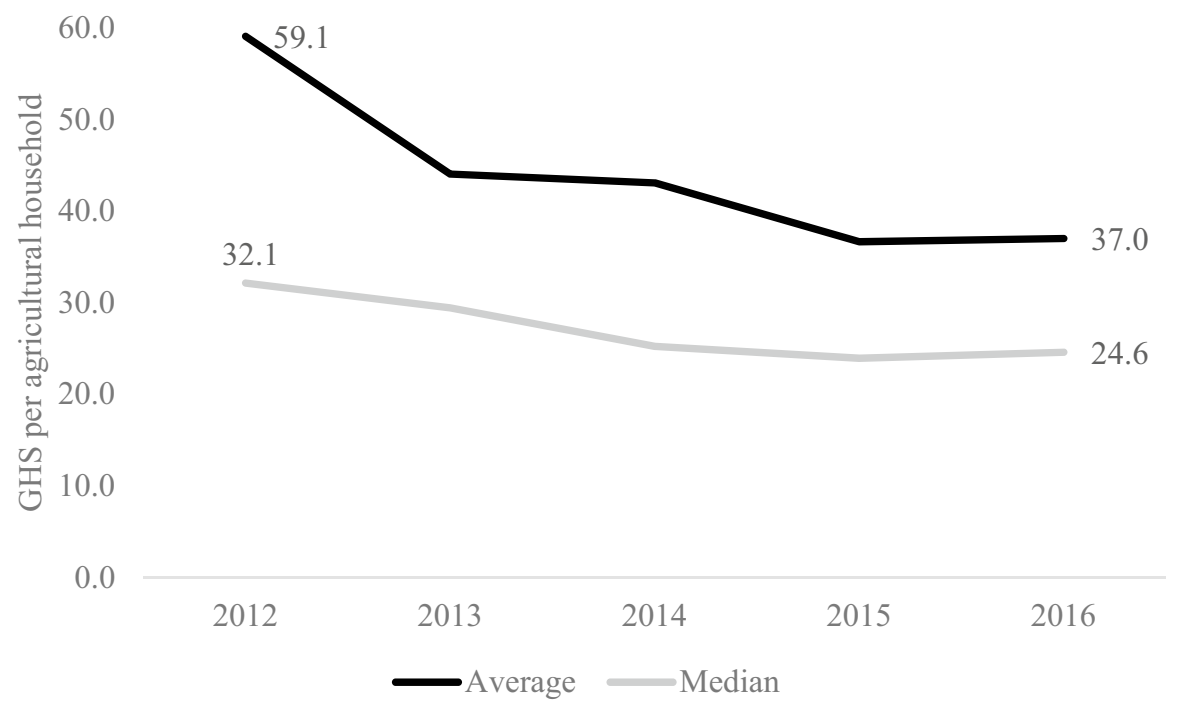

Fig. 3 Distribution of budgeted agricultural expenditures per agricultural household across districts, real terms. Source Calculated from district composite budgets from MoFEP and the district census data. $N=123$ districts

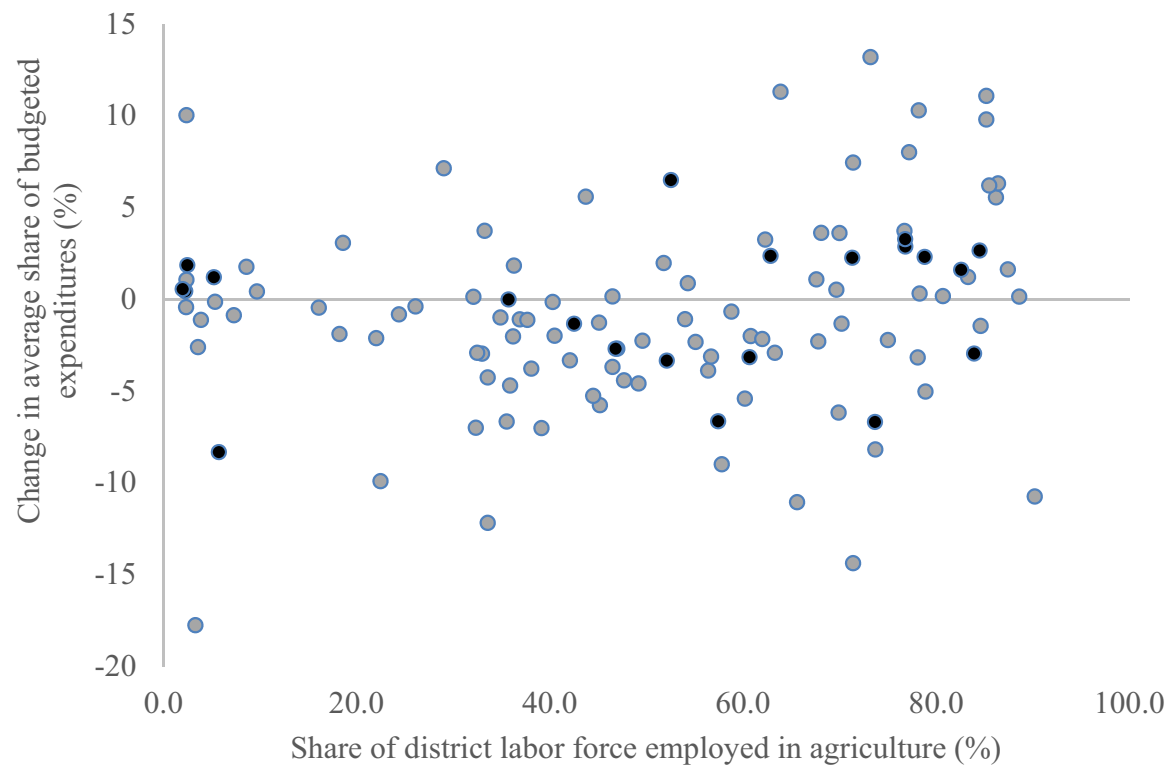

Fig. 4 Change in average share of budgeted agricultural expenditures between 2012-2013 and 20152016. Source Calculated from district composite budgets from MoFEP and the district census data. $N=123$ districts that have full data across all years. Notes Black dots indicate districts that were created in 2012. (Color figure online) 


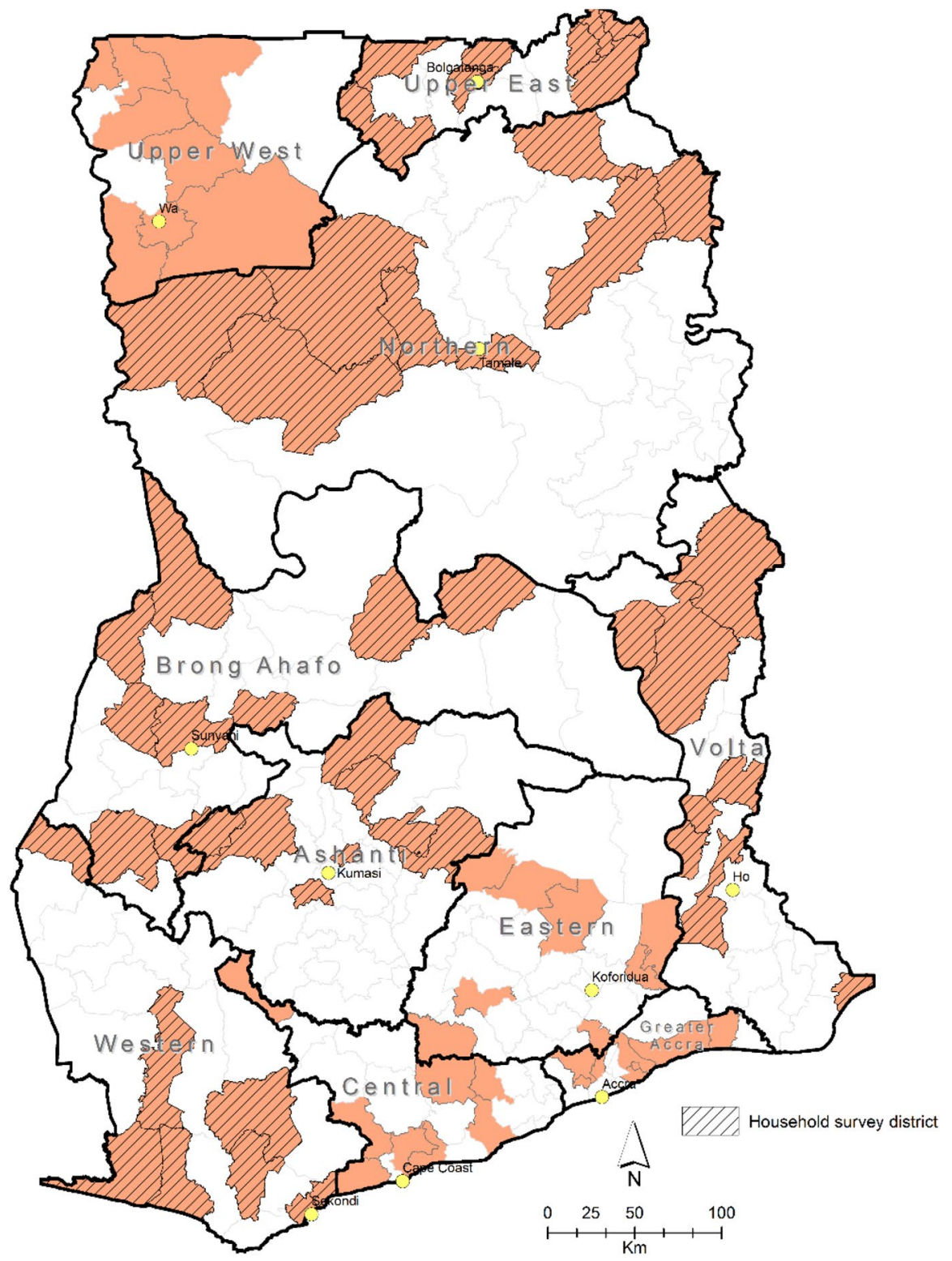

Fig. 5 Map of selected districts for DDA and household surveys

random walk procedure. ${ }^{8}$ Either the head of household or the spouse was eligible to participate in the survey, if they were 18 years of age or older. The household survey

\footnotetext{
${ }^{8}$ Documentation regarding respondent selection is available from IFPRI $2020 \mathrm{~b}$.
}

站 
Table 2 Summary statistics for sampled districts

\begin{tabular}{|c|c|c|c|c|}
\hline \multirow[t]{2}{*}{ Variables } & \multicolumn{2}{|c|}{48 Districts (Household Survey) } & \multicolumn{2}{|c|}{$\begin{array}{l}80 \text { Districts } \\
\text { (DDA Survey) }\end{array}$} \\
\hline & Mean & Standard Deviation & Mean & Standard Deviation \\
\hline Population & 105,948 & 78,504 & 103,965 & 69,828 \\
\hline Poverty rate & 0.34 & 0.18 & 0.45 & 0.22 \\
\hline Number of agricultural households & 11,765 & 5687 & 10,423 & 5642 \\
\hline Share of rural population & 0.66 & 0.24 & 0.62 & 0.28 \\
\hline
\end{tabular}

Sources Population, number of agricultural households, and share of rural population are from GSS (2014). The poverty rate is from GSS (2015)

Table 3 How often have you met with the following groups over the last three months?

\begin{tabular}{lcll}
\hline Group & Never & $1-2$ times & 3 or more times \\
\hline Farmers & 8.8 & 25.0 & 65.8 \\
Researchers with CSIR & 50.0 & 38.8 & 11.3 \\
Regional Agricultural Department (RAD) & 5.0 & 31.3 & 63.8 \\
District Coordinating Director (DCD) & 1.3 & 7.5 & 90.3 \\
District Chief Executive (DCE) & 57.5 & 17.5 & 25.0 \\
Politicians representing this district & 56.3 & 35.0 & 8.8 \\
Traditional authorities & 33.8 & 47.5 & 18.8 \\
Non-governmental organizations & 23.8 & 37.5 & 38.8 \\
Foreign donors & 63.8 & 25 & 11.2 \\
\hline
\end{tabular}

Source District Director of Agriculture Devolution of Agriculture Survey; $N=80$

included a total of 960 households, and interviews were conducted in English, Dagbani, Ewe, Ga, Hausa, and Twi. The full questionnaires and survey data are available at [IFPRI 2020a] and [IFPRI 2020b].

\section{Perspective of Local Bureaucrats}

Studies of decentralization reforms often overlook the impacts on subnational civil servants and the frontline service providers that they supervise. The DDA survey illustrates how these individuals have adjusted to their new roles. The entire sample worked for MoFA from 2008 or earlier and were therefore able to assess how policy formulation and implementation varied before and after the 2012 devolution transition.

Notably, Table 3 highlights that the DCD is the individual with whom the DDAs interact with the most, followed by farmers. By contrast, these bureaucrats have much less contact with political actors, such as the DCEs and assembly members. In other words, despite being the highest level agricultural actor in the district, these DDAs are not engaging frequently with the main political decision-makers within the MMDA to communicate the importance of agriculture. 
The composite budgeting process was viewed unfavorably by the DDA sample, with two-thirds claiming it caused a decrease in disbursements for the sector, and $65 \%$ of respondents claimed that they could not negotiate for sufficient resources during the composite budget planning process. The most commonly identified reason was that agriculture is viewed as less important than other sectors within the district. For instance, one respondent observed, 'The District Assembly is usually concerned with physical structures and our department renders services' (Upper East region) while another noted 'They don't see us as a department that brings money to the district but rather that we take from them' (Greater Accra region). One DCD from Central Region confirmed this challenge: 'During composite budget preparation, much attention is given to physical projects. Politicians are interested in school blocks, CHPS [Community Health Planning and Services] compounds, things that are physical. Agriculture isn't tangible.' 9

The lack of resources impacts staffing and resources to service farmers. On average, DDAs are intended to manage a staff the size of 24 employees. However, with approximately $39 \%$ of staff positions vacant, few are actually managing full staffs. More than $50 \%$ of the DDAs reported that the number of agricultural extension agents has decreased since they arrived in the district.

Most DDAs are committed to making field trips to interact with farmers, with $63 \%$ claiming three or more field visits per month. Yet, $73 \%$ state that they are relying on their own personal resources to fund such visits much more than prior to devolution. Moreover, insufficient budgets mean that $43 \%$ and $41 \%$ said they had no cars or motorbikes, respectively, for extension agents to make field trips, and $86 \%$ noted that their staff lacked any protective gear (e.g., boots, gloves) for visiting fields.

Overall, the DDAs were almost unanimous in identifying decreased resources as the main challenge caused by the reform. For example, a DDA from Central region observed '[There is] no supply of logistics to the field extension officers since the devolution, no motorbikes, no working gear, no fuel for movement, etc. has been provided.' His colleague from Upper East notes, '[The] challenge of negotiating for funds from the assembly is very difficult.' Another DDA from Ashanti region claimed, 'Most of the assemblies treat us as orphans. They don't make development of agriculture a priority.' These findings with respect to decreased resources are largely consistent with those of Agyemang et al. (2014), which focused exclusively on the impacts of the devolution reform at the regional, rather than MMDA, level.

\section{Perspectives of Local Citizens}

If funding for agriculture has declined in aggregate terms and in the views of the DDAs, does this resonate with citizen preferences? The household survey enables us to uncover how well citizens believe they can hold their local governments accountable and their preferences for spending on agriculture versus other sectors.

\footnotetext{
9 All district officials were promised confidentiality through indirect attribution. As such, only the region where they work is identified when providing quotes.
} 
Table 4 Summary statistics of household survey sample

\begin{tabular}{|c|c|c|}
\hline Indicator & Mean & $\begin{array}{l}\text { Standard } \\
\text { Deviation }\end{array}$ \\
\hline Age (years) & 46.0 & 15.6 \\
\hline Female & 0.43 & 0.50 \\
\hline Born in district & 0.72 & 0.45 \\
\hline \multicolumn{3}{|l|}{ Education level } \\
\hline No formal schooling & 0.41 & 0.49 \\
\hline Some primary & 0.15 & 0.36 \\
\hline Primary school completed & 0.16 & 0.37 \\
\hline Some secondary & 0.12 & 0.32 \\
\hline Secondary school completed & 0.11 & 0.31 \\
\hline Some tertiary & 0.06 & 0.23 \\
\hline \multicolumn{3}{|l|}{ Primary occupation } \\
\hline Subsistence agriculture & 0.42 & 0.49 \\
\hline Commercial agriculture & 0.19 & 0.39 \\
\hline Trader/hawker/vendor & 0.15 & 0.36 \\
\hline Professional (teacher, nurse, lawyer, doctor) & 0.04 & 0.20 \\
\hline Skilled manual worker & 0.05 & 0.21 \\
\hline Unskilled manual worker & 0.03 & 0.18 \\
\hline Not working but looking for work & 0.03 & 0.18 \\
\hline Not working and not looking for work & 0.03 & 0.18 \\
\hline Retail/shopkeeping & 0.02 & 0.15 \\
\hline Other & 0.02 & 0.15 \\
\hline Asset index $(0-1)$ & 0.35 & 0.23 \\
\hline Household service index $(0-1)$ & 0.38 & 0.29 \\
\hline News access index $(0-1)$ & 0.74 & 0.43 \\
\hline Household size & 8.0 & 6.0 \\
\hline Inputs received from MMDA in previous agricultural season & 0.15 & 0.35 \\
\hline District extension advice in previous agricultural season & 0.26 & 0.44 \\
\hline
\end{tabular}

Source Ghana Decentralization and Agricultural Services Household Survey, $N=960$

Table 4 first provides an overview of the characteristics of those included in the sample. Since the sample intentionally aimed at including more rural households to assess their experiences with agricultural devolution, most respondents-61\% - are employed in agriculture. Almost three-quarters of the sample have a primary education or less. In addition, most respondents were born in the district, suggesting that they can assess local governance dynamics in the district over time.

While $60 \%$ of respondents admitted the term 'decentralization' had no meaning for them, $80 \%$ had voted in the 2015 local elections and demonstrated an intuitive 
Table 5 Knowledge of, and preferences for, local government leadership

\begin{tabular}{lc}
\hline Variable & $\begin{array}{l}\text { Share of } \\
\text { respondents } \\
(\%)\end{array}$ \\
\hline Knows correct name of DCE & 35.1 \\
Knows correct name of DA & 66.8 \\
Would you prefer to elect your DCE? & \\
Yes & 48.4 \\
No & 17.6 \\
Don't know & 33.0 \\
If DA did not achieve his/her campaign promises, what would you \\
$\quad$ do? \\
Select different candidate \\
Give him/her another chance \\
Abstain \\
Don't know
\end{tabular}

Source Ghana Decentralization and Agricultural Services Household Survey, $N=960$

understanding that local government should ideally be accountable to citizens. ${ }^{10}$ This manifests in a number of ways. First, while only one-third knew the names of their appointed DCE, two-thirds knew the name of their elected assembly member (Table 5). This was determined by first asking the respondent to give the name of their assembly member, and then subsequently confirming whether that name corresponded with the 2015 local election results. ${ }^{11}$ Second, a plurality of the sample expressed a preference for electing their DCE rather than have him/her appointed by the president. Common reasons for this position centered on the importance of accountability: 'To allow citizens to choose who they think is best and can help build the community' (male in Ahafo-Ano North), and 'We are here with them and know them well so, we the citizens are the right people to choose them, not the government' (male, Asunafo North). These sentiments affirm Antwi-Boasiako's (2010) observations that Ghanaians generally are in favor of decentralization as a modality of citizen empowerment. Third, $86 \%$ noted that they would vote out their elected assembly person if s/he did not deliver on campaign promises, indicating that respondents view their vote as a tool to sanction local politicians. Finally, when faced with two service delivery scenarios, related to poor agricultural extension services and roads filled with potholes, respondents by far identified their elected assembly member as the first person they would contact to rectify these problems (see Fig. 6). Collectively, these patterns suggest that many of the sample's respondents know and engage with their Assembly members. As noted by Yeboah-Assiamah

\footnotetext{
10 According to Yeboah-Assiamah et al. (2014), turnout in Ghana's local elections is generally low but higher in rural areas, which is where this study's survey predominantly was concentrated.

11 These are published in the Ghana Gazette Notice on Results of the 2015 District Assembly Elections.
} 
60

50

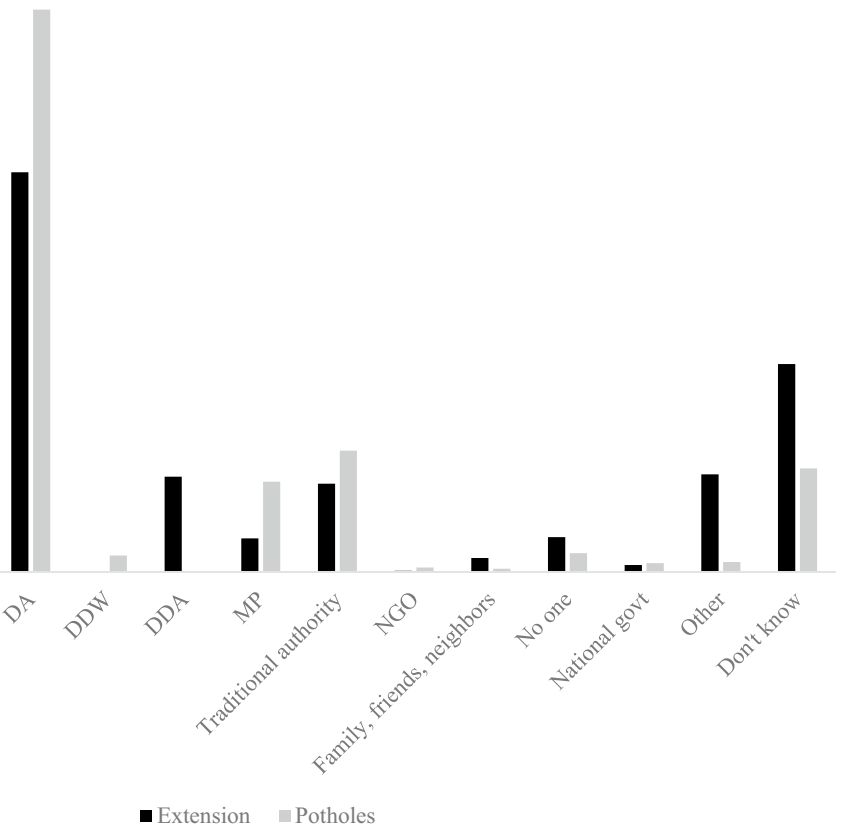

Fig. 6 Primary individual to consult when services are not performing. DCE-district chief executive, DCD- district coordinating director, DA—elected district assembly member, DDW—district director of works, DDA - district director for agriculture, MP-Member of Parliament. The response rates correspond to the following two vignettes: (1) 'Gladys is a farmer. Her MMDA promised to provide more agricultural extension agents (AEAs) for farmers in her district. However, 10 months later, she has not received a field visit from an AEA. If you were in Gladys' position, who would be the first person you would talk to in order to address the situation?' (2) 'The roads in Daniel's community are filled with potholes. His MMDA promised to fix the roads. However, 10 months later, nothing has been done. If you were in Daniel's position, who would be the first person you would talk to in order to address the situation?'

et al. (2014), such dynamics can be especially important in rural areas where communities are smaller and there are informal modalities-including community meetings, naming ceremonies, religious events, and festivities organized by traditional authorities - that facilitate interaction with local politicians. ${ }^{12}$

\section{Drivers of Policy Preferences}

As noted earlier, improved preference matching between the package of taxes and services that citizens desire is one of the espoused aims of decentralization (Oates 1972). To elicit information about preferences, households were asked what area of

${ }^{12}$ For example, almost $71 \%$ of respondents attended a community meeting over the previous 12 months. 


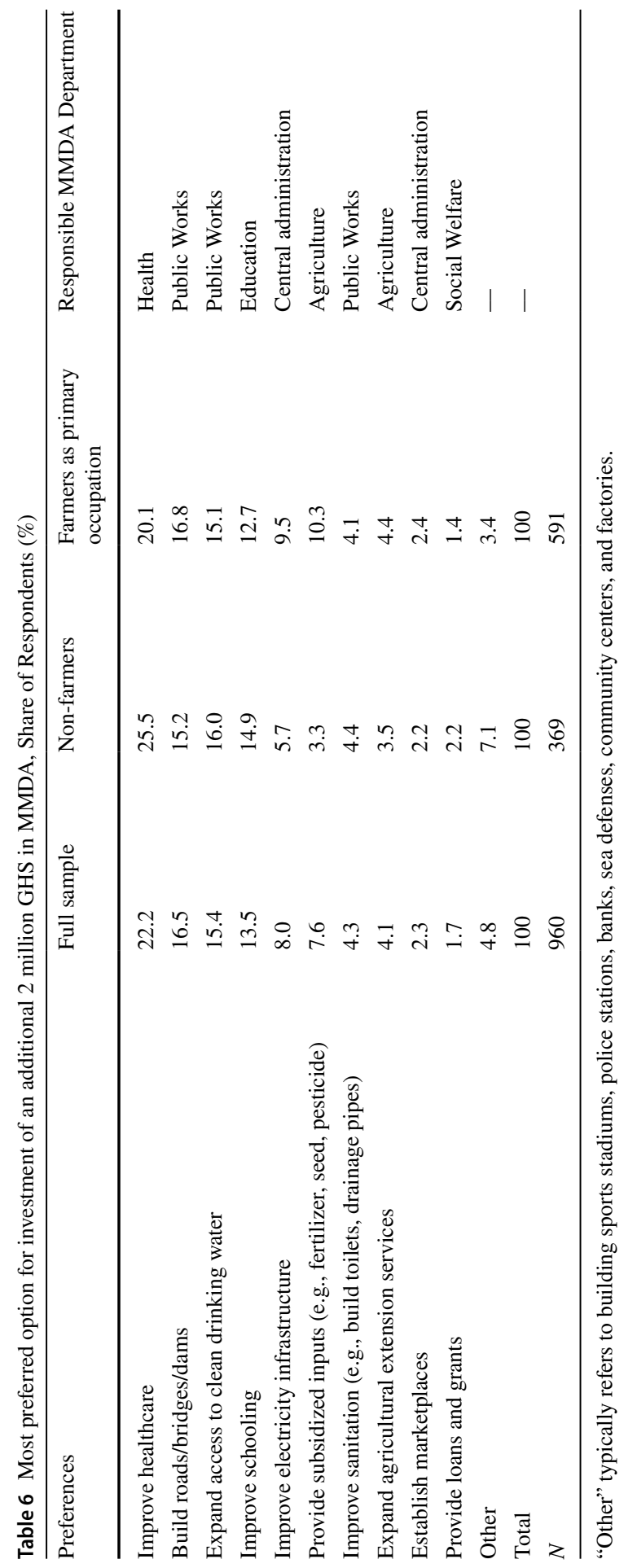

s. 
investment they would prioritize in their district if the MMDA raised an additional 2 million GHS (approximately USD 475,000) from district residents' tax revenue. This phrasing was intended to force the respondents to choose only one item; by contrast, techniques such as Likert scales do not force respondents to consider tradeoffs between policies, and the interpretation of the options on such scales can be highly subjective among respondents (Lusk and Briggeman 2009). Table 6 highlights that agricultural goods and services are given higher priority among farmers than non-farmers, with more support for visible and targeted subsidized inputs than for less visible agricultural extension. Yet, among both groups, healthcare and public works receive the most support.

When considered in tandem with the budgeted expenditures presented in Table 1, there is some congruence between citizens' ranking of priorities and sectoral allocations. Agriculture ranks just above social welfare, physical planning, and disaster management in terms of its share in total expenditures. This largely corresponds to where it ranks in citizen priorities. Supporting the views of the DDAs, the largest share of respondents prioritize physical, visible investments, with more than $36 \%$ of the full sample preferring an investment that falls under the mandate of the public works department. Therefore, in the sectors that have been devolved, budgeting in this sub-sample does appear to follow citizen preferences, even in a largely rural sample where one would otherwise expect that preferences for agricultural spending would be high.

Yet, if citizens generally de-prioritize low visibility goods, what explains the share of respondents in Table 6 who nonetheless would value more investments in agriculture? To better understand the drivers of these preferences, a logit model was estimated that captures whether a respondent prefers her tax money to be used on those services that fall under the MMDA's agricultural budget. A standard set of demographic controls were included, such as gender, age, education, and household size, as well as the socioeconomic status of respondents. For the latter, an asset index, ranging from 0 to 1 , was constructed capturing whether a respondent's household has a mobile phone, computer, refrigerator, fan, stove, television, bike, and car (see Table 4). In addition, a services index was created based on whether a household has piped water, electricity from the national grid, and a flush toilet. Respondents from households that are lower on this index could be more likely to prefer spending on public works options rather than on agricultural services. Similarly, household size would indicate whether the respondent has a large number of children in the household, which could potentially influence preferences for education. A news index, which consists of how frequently a respondent obtains news from the radio, television, newspaper, and/or internet, is included as a proxy for how informed citizens are of local service delivery issues.

A dummy variable is also included for whether a respondent is a farmer. In Model 2 , the types of farmers are further disaggregated into subsistence and commercial. Relatedly, if someone has received inputs, for fertilizer, seed, or pesticides, by their MMDA in the previous agricultural season, they may be more likely to see the value of investments in agriculture. Similarly, a respondent who received advice from a district extension officer in the last season would be more likely to recognize the benefits of investments in such services than someone who did not. Both inputs and 


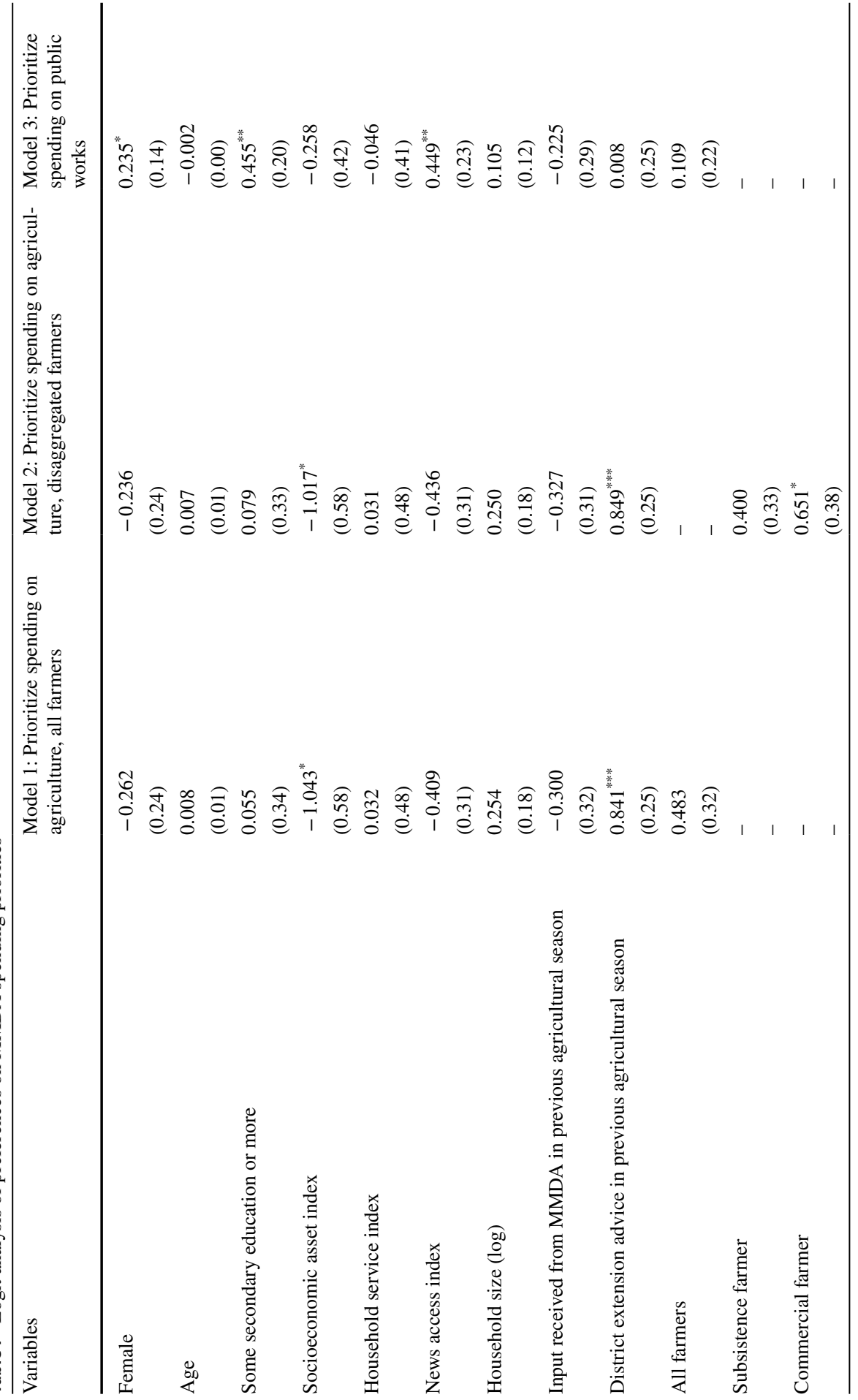

站。 


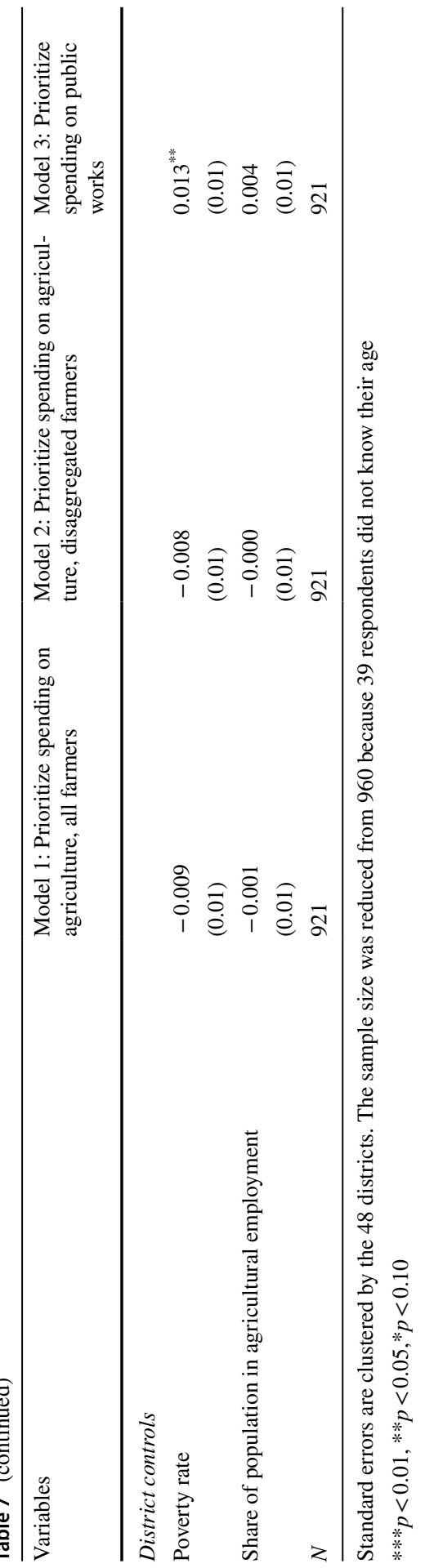


extension advice are not just limited to those who identified their primary occupation as farming; the question was asked to anyone who owned any land or planted crops in the previous 12 months. Two district-level variables - the poverty rate and the share of the labor force employed in the agricultural sector-were included as controls to identify if socioeconomic variation across districts may also account for disparities in preferences for agricultural spending.

The findings in Table 7 highlight that the most substantively and statistically significant driver of support for prioritizing agriculture spending is receipt of extension advice in the previous agricultural season. In terms of the odds ratio, a respondent who received extension advice is 2.3 times more likely to prioritize agriculture spending than someone who did not. This resonates with the view that extension is a low visibility public good and unless someone is aware of its benefits, they are unlikely to prioritize allocating their money to that service. For those who have benefitted from having an extension agent provide advice, continued spending on agriculture is a worthy priority. Model 2 suggests that commercial farmers are the most likely to favor improved agricultural spending, reflecting that they are mostly likely to use improved varieties of inputs to gain better quality yields in order to obtain a higher profit.

A third logit model was run as a placebo test and examines whether a respondent prefers the use of her tax money on services that fall under the MMDA's public works budget. If receipt of extension services in the previous agricultural season is a significant driver of respondents' preferences for prioritizing agricultural spending, then this same variable should not also explain preferences for public works spending. Indeed, Model 3 indicates that a different set of factors explains preferences for spending in that sector, including most significantly education and frequent engagement with the news, as well as living in a district with higher poverty. In other words, more informed individuals living in worse-off districts are more likely to view public works expenditures as a more important investment for their tax money.

\section{Discussion}

The previous sections demonstrated that based on a number of indicators, Ghanaian citizens value the ability to hold their local government accountable through elections. However, with the devolution of the agriculture and public works sectors in Ghana since 2012, budgeted expenditures for agricultural functions have declined across districts while that for public works has increased. The DDAs verified that the level of resources has fallen, increasingly leading them to personally fund more of their field visits, and they confirm that the number of extension agents they oversee has decreased since the 2012 reform. Simultaneously, there is no clear association between budgeted expenditures for agriculture and key socioeconomic characteristics that would be assumed to influence spending on the sector, such as the share of those employed in the sector. Even in districts with high levels of agricultural employment, only a small share of citizens favor more investment in agricultural 
services while a plurality prefer investments that fall under the mandate of the MMDA's public works department.

Importantly, those who do favor more spending in agriculture benefitted from extension advice from their MMDA in the previous agricultural season. This suggests that this low visibility service can only be appreciated by those who directly benefitted from receiving the knowledge shared by extension agents. Opalo (2020) uncovered similar dynamics in Kenya whereby those who were most likely to be exposed to the healthcare system, namely women of childbearing age, were most likely to prefer healthcare services to be a devolved function.

\section{Conclusions}

Faguet (2014, p. 24) laments that many decentralization studies become pre- and post-reform 'exercises in comparative statics' but fail to examine the underlying policy processes. By contrast, this paper integrates district budget data, bureaucratic experiences, and household perspectives to holistically consider how giving local politicians more budget autonomy could affect the provision of low visibility public goods. If devolution is intended to both enhance accountability for service provision and improve preference matching, and if a majority of local citizens prefer more visible goods and services, then these will be more likely to be prioritized by politicians who fear being ousted from office.

On the one hand, the specificities of Ghana's local elections-non-concurrency and non-partisanship of candidates-likely make the dynamics analyzed here particularly pronounced and by extension, such institutional factors should similarly influence the impacts of devolution in other settings. Indeed, Hasnain (2010) finds in Pakistan, where local elections are also non-concurrent and legally non-partisan, that devolution resulted in increased spending toward physical infrastructure favored by citizens. On the other hand, similar findings have emerged in Uganda (Akin et al. 2005) and Kenya (World Bank 2019), even though both countries hold local elections on a partisan basis and Kenya does so concurrently as well. Moreover, given the appointment of DCEs at the MMDA level, it is likely that the patterns observed in Ghana are likely to be even more pronounced in settings where both the assembly and the executive members are elected at the subnational level. Comparative work across countries that vary with respect to their subnational electoral rules would further elucidate the generalizability of this study.

More broadly, the findings have important implications for policy coherence. Following Herrera and Post's (2014) work on the dual processes of decentralization and water sector privatization, the analysis highlights the incompatibility between certain decentralization reforms and sectoral development targets. This is particularly true in Africa where more than $75 \%$ of countries in the region now have some form of subnational elections (Resnick 2020). In 2014, 17 heads of state committed to the 2014 African Union (AU) Declaration on Decentralization, and additional countries are devolving agricultural services, such as Kenya, Malawi, and Zambia. Also in 2014, African presidents committed as part of the Malabo Declaration to increase agricultural spending and services under the AU's Comprehensive Africa 
Agriculture Development Program (CAADP). This study suggests, however, that significant trade-offs exist across these high-level policy commitments; if devolution causes agriculture to become sidelined by local politicians who believe it is more electorally rewarding to allocate budgets to health, public works, or education, then meeting the CAADP commitments will be increasingly difficult. ${ }^{13}$

Finally, much of the work on the political economy of distribution has relatively weak micro-foundations, with preferences assumed based on one's median income, geographical location, ethnicity, or party affiliation (see Golden and Min 2013). This study emphasizes the need for more fine-grained, empirical investigation into actual citizen preferences and priorities by providing a more in-depth investigation of how they would prefer their tax money to be allocated and considering how that feeds into politicians' priorities within the budgeting process. The findings show that there is still sizeable heterogeneity in preferences within subnational administrative units, and preference matching ultimately requires local governments, like their national counterparts, to still make trade-offs in resource allocations.

Acknowledgements Support for this study was generously provided by USAID through IFPRI's Ghana Strategy Support Program (EEM-G-00-04-00013), USAID through the Feed the Future Innovation Lab Food Security Project, and the CGIAR Research Program on Policies, Institutions, and Markets (PIM) led by IFPRI. The author is grateful for feedback provided by Ruth Carlitz, Shashi Kolavalli, Karl Pauw, Sam Benin, Daniel Ohemeng Boateng, Josephine Quagraine, Dorothy Affa, Angela Dansson, and Kwaku Owusu Baah. John Agandin, Bhavna Sivasubramanian, and Mekamu Kedal provided wonderful research assistance. The Center for Democratic Development-Ghana (CDD-Ghana) implemented the surveys under the leadership of Daniel Attah Armoh. The author also thanks the 10 Regional Agricultural Directors in Ghana who shared the contacts of their district staff to facilitate the DDA surveys. The surveys were approved by IFPRI's Institutional Review Board, approval \#00007490. All errors are those of the author and do not necessarily reflect those of IFPRI, PIM, or the CGIAR.

\section{Declarations}

Conflict of interest There is no conflict of interest.

Open Access This article is licensed under a Creative Commons Attribution 4.0 International License, which permits use, sharing, adaptation, distribution and reproduction in any medium or format, as long as you give appropriate credit to the original author(s) and the source, provide a link to the Creative Commons licence, and indicate if changes were made. The images or other third party material in this article are included in the article's Creative Commons licence, unless indicated otherwise in a credit line to the material. If material is not included in the article's Creative Commons licence and your intended use is not permitted by statutory regulation or exceeds the permitted use, you will need to obtain permission directly from the copyright holder. To view a copy of this licence, visit http://creativecommons.org/licen ses/by/4.0/.

\section{References}

Agyemang, K., F. Nzegwu, C. Addae, and F. Agoabasa. 2014. Strengthening Ghana's Regional Agricultural Department (RAD) in the Context of the Ongoing Decentralisation Process: An Assessment of

\footnotetext{
13 A larger consideration, beyond the scope of this paper, is that agricultural transformation likely requires concurrent expenditures in complementary sectors, including public works.
} 
Past and Current Capabilities. Volume 1-Main Report. Washington, DC: Development Alternatives International.

Akin, J., P. Hutchinson, and K. Strumpf. 2005. Decentralisation and Government Provision of Public Goods: The Public Health Sector in Uganda. Journal of Development Studies 41 (8): 1417-1443.

Antwi-Boasiako, K. 2010. Public Administration: Local Government and Decentralization in Ghana. Journal of African Studies and Development 2 (7): 166-175.

Arze del Granado, F.J.A., J. Martinez-Vazquez, and R. McNab. 2018. Decentralized Governance, Expenditure Composition, and Preferences for Public Goods. Public Finance Review 46 (3): 359-388.

Barkan, J., and J. Okumu. 1974. Political Linkage in Kenya: Citizens, Local Elites, and Legislators. Iowa City: Comparative Legislative Research Center, University of Iowa.

Batley, R., and C. Mcloughlin. 2015. The Politics of Public Services: A Service Characteristics Approach. World Development 74: 275-285.

Besley, T., and M. Ghatak. 2007. Reforming Public Service Delivery. Journal of African Economies 16 (1): $127-156$.

Brierley, S. 2020. Unprincipled Principals: Co-opted Bureaucrats and Corruption in Ghana. American Journal of Political Science 64 (2): 209-222.

Brinkerhoff, D., and O. Azfar. 2010. Decentralization and Community Empowerment. In Making decentralization work: Democracy, Development, and Security, ed. E. Connerly, K. Eaton, and P. Smoke. Boulder, CO: Lynne Rienner Publishers.

Cheema, G.S., and D. Rondinelli. 2007. From Government Decentralization to Decentralized Governance. In Decentralizing Governance: Emerging Concepts and Practices, ed. G.S. Cheema and D. Rondinelli. Cambridge, MA: Harvard University and Brookings Institution Press.

Cheibub, J.A., and A. Przeworski. 1999. Democracy, Elections, and Accountability for Economic Outcomes. In Democracy, Accountability, and Representation, ed. A. Przeworski, S. Stokes, and B. Manin. Cambridge: Cambridge University Press.

D'Arcy, M., and A. Cornell. 2016. Devolution and Corruption in Kenya: Everyone's Turn to Eat? African Affairs 115 (459): 246-273.

De Kadt, D., and E. Lieberman. 2017. Nuanced Accountability: Voter Responses to Service Delivery in Southern Africa. British Journal of Political Science 50: 185-215.

Eaton, K., K. Kaiser, and P. Smoke. 2010. The Political Economy of Decentralization Reforms: Implications for Aid Effectiveness. Washington, DC: World Bank.

Faguet, J.P. 2012. Decentralization and Popular Democracy: Governance from Below in Bolivia. Ann Arbor: University of Michigan Press.

Faguet, J.P. 2014. Decentralization and Governance. World Development 53 (January): 2-13.

Faguet, J.P., and F. Sánchez. 2008. Decentralization's Effects on Educational Outcomes in Bolivia and Colombia. World Development 36 (7): 1294-1316.

Ghana Statistical Services (GSS). 2014. District Analytical Reports: 2010 Population and Housing Census. Accra, Ghana: GSS.

Ghana Statistical Service (GSS). 2015. Ghana Poverty Mapping Report. Accra, Ghana: GSS.

Golden, M., and B. Min. 2013. Distributive Politics Around the World. Annual Review of Political Science 16: 73-99.

Government of Ghana (GoG). 2016. Local Governance At, 2016, Act 936. Accra, Ghana: Government of Ghana.

Government of Ghana (GoG). 2009. Local Government Instrument, 2009. L.I. 1961. Accra, Ghana: Government of Ghana.

Gulzar, S., and B. Pasquale. 2017. Politicians, Bureaucrats, and Development: Evidence from India. American Political Science Review 111 (1): 162-183.

Harding, R. 2015. Attribution and Accountability: Voting for Roads in Ghana. World Politics 67 (4): 656-689.

Hasnain, Z. 2010. Devolution, Accountability, and Service Delivery in Pakistan. The Pakistan Development Review 49 (2): 129-152.

Herrera, V., and A. Post. 2014. Can Developing Countries Both Decentralize and Depoliticize Urban Water Services? Evaluating the Legacy of the 1990s Reform Wave. World Development 64 (December): 621-641.

Hickey, S., and G. Mohan. 2008. The Politics of Establishing Pro-poor Accountability: What Can Poverty Reduction Strategies Achieve? Review of International Political Economy 15 (2): 234-258. 
International Food Policy Research Institute (IFPRI). 2020a. District Director of Agriculture in Ghana Survey. Washington, DC: IFPRI. Available at: https://doi.org/10.7910/DVN/HDVKK4. Harvard Dataverse. Version 1.

International Food Policy Research Institute (IFPRI). 2020b. Ghana Decentralization and Agricultural Services Household Survey. Washington, DC: IFPRI. Available at: https://doi.org/10.7910/ DVN/RQ0DWH. Harvard Dataverse. Version 1.

Joshi, A. 2013. Do They Work? Assessing the Impact of Transparency and Accountability Initiatives in Service Delivery. Development Policy Review 31 (S1): S29-S48.

Lindberg, S. 2010. What Accountability Pressures do MPs in Africa Face and How Do They Respond? Evidence from Ghana. Journal of Modern African Studies 48 (1): 117-142.

Lusk, J., and B. Briggeman. 2009. Food Values. American Journal of Agricultural Economics 91 (1): 184-196.

Maiorano, D., U. Das, and S. Masiero. 2018. Decentralisation, Clientelism and Social Protection Programmes: A Study of India's MGNREGA. Oxford Development Studies 46 (4): 536-549.

Mani, A., and S. Mukand. 2007. Democracy, Visibility, and Public Good Provision. Journal of Development Economics 83 (2): 506-529.

Mehrotra, S. 2006. Governance and Basic Social Services: Ensuring Accountability in Service Delivery through Deep Democratic Decentralization. Journal of International Development 18: $263-283$.

Ministry of Food and Agriculture (MoFA). 2018. Investing for Food and Jobs (IFJ): An Agenda for Transforming Ghana's Agriculture (2018-2021). Accra, Ghana: Ministry of Food and Agriculture.

Mogues, T. 2015. What Determines Public Expenditure Allocations? A Review of Theories, and Implications for Agricultural Public Investments. European Journal of Development Research 27 (3): 452-473.

Mogues, T., and K. Omusu-Baah. 2014. Decentralizing Agricultural Public Expenditures: Findings from a Scoping Study at the Onset of a New State in Ghana's Decentralization Reform. Working Paper No. 37. Washington, DC: Ghana Strategy Support Program of the International Food Policy Research Institute.

Oates, W. 1972. Fiscal Federalism. New York: Harcourt Brace Jovanovich.

Oates, W. 1985. Searing for Leviathan: An Empirical Study. American Economic Review 75: 748-757.

Opalo, K. 2020. Citizen Political Knowledge and Accountability: Survey Evidence on Devolution in Kenya. Governance 33 (4): 849-869.

Organized for Economic Cooperation and Development (OECD). 2019. Making Decentralisation Work: A Handbook for Policy-Makers. Paris, France: OECD.

Pauw, K., and J. Thurlow. 2015. Prioritizing Rural Investments in Africa: A Hybrid Evaluation Approach Applied to Uganda. The European Journal of Development Research 27 (3): 407-424.

Ragasa, C., and J. Mazunda. 2018. The Impact of Agricultural Extension Services in the Context of a Heavily Subsidized Input System: The Case of Malawi. World Development 105: 25-47.

Rasul, I., and D. Rogger. 2018. Management of Bureaucrats and Public Service Delivery: Evidence from the Nigerian Civil Service. Economic Journal 128 (February): 413-446.

Resnick, D. 2020. The Politics of Urban Governance in sub-Saharan Africa. Regional and Federal Studies. https://doi.org/10.1080/13597566.2020.1774371.

Schedler, A. 1999. Conceptualizing Accountability. In The Self-Restraining State: Power and Accountability in New Democracies, ed. A. Schedler, L. Diamond, and M. Plattner, 13-28. Lynne Rienner: Boulder, CO.

Skoufias, E., A. Narayan, B. Dasgupta, and K. Kaiser. 2014. Electoral Accountability and Local Government Spending in Indonesia. Policy Research Working Paper No. 6782. Washington, DC: World Bank.

Smoke, P. 2015. Accountability and Service Delivery in Decentralizing Environments: Understanding Context and Strategically Advancing Reform. In A Governance Practitioner's Notebook: Alternative Ideas and Approaches, ed. A. Whaites, E. Gonzalez, S. Fyson, and G. Teskey, 219-232. Paris: Organization for Economic Cooperation and Development.

Stokes, S. 2011. Political Clientelism: Chapter 31. In The Oxford Handbook of Political Science, ed. R. Goodin. Oxford: Oxford University Press.

Svolik, M. 2013. Learning to Love Democracy: Electoral Accountability and the Success of Democracy. American Journal of Political Science 57: 685-702. 
Tiebout, C. 1956. A Pure Theory of Local Expenditures. Journal of Political Economy 64 (5): $416-424$.

Turner, M. 2002. Whatever Happened to deconcentration? Recent initiatives in Cambodia. Public Administration and Development 22 (4): 353-364.

Umali-Deininger, D. 1997. Public and Private Agricultural Extension: Partners or Rivals? The World Bank Research Observer 12 (2): 203-224.

Yeboah-Assiamah, E. 2016. Power to the People! How far has the Power Gone to the People? A Qualitative Assessment of Decentralization Practice in Ghana. Journal of Asian and African Studies 51 (6): 683-699.

Yeboah-Assiamah, E., K. Asamoah, and A. Osei-Kojo. 2014. The Concept of Administrative Responsibility: An Alternative Explanation for Poor Voter Turnout in Local Government Elecitons Using Empirical Evidence from Techiman Municipality, Ghana. International Journal of Politics and Good Governance 5 (53): 1-34.

Wallis, J.J., and W.E. Oates. 1988. Decentralisation in the Public Sector: An Empirical Study of State and Local Government. In Fiscal Federalism: Quantitative Studies, ed. H.S. Rosen. Chicago: University of Chicago Press.

Williams, M. 2017. The Political Economy of Unfinished Development Projects: Corruption, Clientelism, or Collective Choice? American Political Science Review 111 (4): 705-723.

World Bank. 2019. Project Performance Assessment Report: Kenya Agricultural Productivity Program, KAAP I and II. Washington, DC: Independent Evaluation Group, World Bank.

Publisher's Note Springer Nature remains neutral with regard to jurisdictional claims in published maps and institutional affiliations. 